\title{
ОСОБЕННОСТИ ПРАВОВОГО СТАТУСА ПОЛУЧАТЕЛЯ ГРУЗА В ДОГОВОРЕ ПЕРЕВОЗКИ ПО ЗАКОНОДАТЕЛЬСТВУ РОССИЙСКОЙ ФЕДЕРАЦИИ
}

\section{FEATURES OF THE LEGAL STATUS OF THE CONSIGNEE IN THE CONTRACT \\ OF CARRIAGE UNDER THE LEGISLATION OF THE RUSSIAN FEDERATION}

A. Spector

Summary: This article discusses the legal status of the consignee in the contract of carriage. It is concluded that the consignee acts as a third party on the side of the shipper in the relations of cargo transportation, since the shipper and the consignee have a binding relationship from another contract between them, where the sender undertakes to provide the recipient with certain things through the use of the carrier's transport services.

Keywords: contract of carriage, code, consignee, sender, freedom of contract, goods, obligations of the parties.

\author{
Спектор Асия Ахметовна \\ Д.ю.н., профессор, Российский университет \\ транспорта, г. Москва. \\ spektor_roat_dot@bk.ru
}

Аннотация: В настоящей статье рассмотрен правовой статус получателя груза в договоре перевозки. Сделан вывод о том, что грузополучатель в отношениях перевозки груза выступает третьим лицом на стороне грузоотправителя, так как у грузоотправителя и грузополучателя существует обязательственная связь из иного договора между ними, где отправитель обязуется предоставить получателю определенные вещи посредством использования транспортных услуг перевозчика.

Ключевые слова: договор перевозки, кодекс, получатель груза, отправитель, свобода договора, товар, обязательства сторон.

ным становится комплексный характер обязательств, вытекающих из этого договора, которые содержат элементы иных видов обязательств.

Договор перевозки представляет собой самостоятельный гражданско-правовой договор, а, следовательно, нужно говорить об особом типе обязательств, отличном от других гражданско - правовых обязательств.

Права и обязанности получателя груза во многом обусловлены конкретными услугами, оказываемыми им. При этом его некоторые права и обязанности закреплены законодателем в соответствующих нормах, регламентирующих отношения по транспортной деятельности в наиболее общем виде. Руководствуясь принципом свободы договора, исходя из своих фактических потребностей, грузоотправитель и грузополучатель могут предусмотреть в договоре права и обязанности, которые являются для них важными и отражают существо конкретного правоотношения.

Таким образом, особенности правового статуса получателя груза предопределены конструкцией договора в пользу третьего лица, которая предусматривается в ст. 430 ГК РФ [1]. В частности, указанная статья находится в общих положениях о договорах (подраздел 2 раздела III ГК РФ), что означает универсальность ее применения ко всем остальным видам договоров. В частности, данная 
конструкция применима к правоотношениям, вытекающим из договора перевозки груза в п. 1 ст. 785 ГК РФ [2]. В качестве кредитора выступает грузоотправитель, должника - перевозчик, а третьего лица - грузополучатель.

В свою очередь, грузополучатель является управомоченным на получение груза лицом. Поскольку договор перевозки груза зачастую заключается в дополнение к договору поставки (купли-продажи), заключаемому между грузоотправителем (поставщик) и грузополучателем (покупатель), с условием о доставке груза силами поставщика до склада покупателя. В таком случае груз является товаром, так как он продается покупателю по отдельному от договора перевозки груза договору. При самовывозе со склада поставщика товара (груза) силами покупателя при привлечении перевозчика грузоотправителем и грузополучателем будет одно и то же лицо, а значит, конструкция договора в пользу третьего лица в таком случае неприменима.

Обращаясь к рассмотрению позиций, изложенных в научной литературе, отметим, что существует достаточно большое количество аргументированных мнений. Так, в научной литературе существуют различные точки зрения относительно того, является ли договор перевозки груза в пользу грузополучателя договором в пользу третьего лица. Общепринятой точкой зрения, реализованной в положениях ГК РФ, является точка зрения, согласно которой договор перевозки груза является договором в пользу третьего лица, уполномоченного отправителем на получение груза. Такой вывод следует также из иных федеральных законов, регулирующих отношения перевозки грузов: Воздушного кодекса РФ [3], Кодекса торгового мореплавания РФ [4] и др.

Вместе с тем, полагаем, что не следует забывать о том, что регулирование гражданско-правовых отношений между грузоотправителем и перевозчиком не является единственной задачей транспортных уставов и кодексов. По своей правовой природе транспортное право является комплексной правовой наукой, включающей в себя помимо регулирования перевозочных отношений обеспечение транспортной безопасности, вопросы государственного управления, земельные, трудовые и иные отношения в сфере транспорта. Из этого можно сделать вывод, что законодатель при формировании транспортных уставов и кодексов отдал предпочтение регулированию вопросов публичного права, оставляя свободу сторонам в построении частных взаимосвязей путем вступления в договорные правоотношения.

В частности, М.К. Александров-Дольник придерживаются точки зрения, согласно которой грузополучатель и грузоотправитель являются одной стороной в договоре перевозки груза [5. С. 107]. В опровержение данной позиции можно заявить, что в отношениях между грузопо- лучателем и перевозчиком нет взаимности, встречного удовлетворения, так как их правовые взаимоотношения не находятся в одной плоскости. Отправитель и получатель груза обладают неодинаковым объемом полномочий и ответственности в отношениях с перевозчиком и могут являться абсолютно разными компаниями, что не может служить в пользу признания данной конструкции верной. В то же время из данной конструкции можно извлечь полезный вывод - грузополучатель является третьим лицом со стороны грузоотправителя, то есть грузоотправитель и грузополучатель в отношениях перевозки груза выступают на одной «стороне», однако такую сторону нельзя признавать в качестве стороны обязательства.

Следующей точки зрения придерживается В.К. Шайдуллина [8. С. 22], она заключается в том, что договор перевозки груза представляет собой трехсторонний договор, где получатель груза является третьей стороной со своими правами и обязанностями. Однако такая позиция не соответствует п. 3 ст. 154 ГК РФ, так как получатель груза не выражает своей воли на заключение договора перевозки груза, грузоотправитель заключает его самостоятельно с перевозчиком, предоставляя получателю груза лишь правообязанность по получению такого груза.

Получатель груза может выразить свою волю касательно выбора типа перевозки товара, конкретной транспортной организации, даты и времени доставки товара в договоре поставки товаров, заключаемом между отправителем (поставщиком) и получателем (покупателем), однако это не означает выражение воли покупателя на заключение договора перевозки груза. Более того, перевозчик не участвует в исполнении договора поставки.

В научной литературе также выделяют в отношениях перевозки одностороннюю сделку перевозчика по передаче груза получателю груза [7. С. 46] и одностороннюю сделку грузополучателя по принятию груза. Однако грузополучатель и перевозчик связаны единым обязательством из договора, их права и обязанности отчасти являются корреспондирующими.

Следует признать, что помимо положений закона значительное число теоретиков права также признают в договоре перевозки груза реализацию конструкции договора в пользу третьего лица. Из их числа можно выделить таких ученых, как М.И. Брагинский, В.В. Витрянский [6. С.293] и многих других. Вместе с тем, в отличие от конструкции договора в пользу третьего лица договор перевозки груза в силу закона устанавливает для грузополучателя определенные гражданско-правовые обязанности. Подобное наложение обязанностей на лицо, не являющееся стороной в договоре, порождает у ряда 
ученых сомнения относительно правовой квалификации договора перевозки груза в пользу грузополучателя.

Далее, неисполнение своих обязанностей грузополучателем как третьим лицом в договоре перевозки груза влечет также наступление предусмотренной законом ответственности. Следовательно, можно сделать вывод, что по общему правилу императивное установление ответственности для третьего лица в обязательстве также является исключением из общего правила п. 3 ст. 308 ГК РФ. Так, в качестве ответственности за непринятие груза от перевозчика для грузополучателя предусмотрено удержание груза до оплаты причитающихся перевозчику сумм (ч. 2 ст. 160 КТМ РФ). Также возможны ситуации, при которых грузоотправитель в транспортных документах ошибочно указывает иного получателя груза, который никак не связан с самим грузоотправителем. На такого ошибочно указанного получателя груза в силу закона устанавливаются гражданско-правовые обязанности, за неисполнение или ненадлежащее исполнение которых наступает ответственность. Без наличия между грузоотправителем и грузополучателем обязательственной связи наложение каких-либо обязанностей на третье лицо является неразумным и несправедливым.

В завершение сделаем следующие выводы. В действующей российской правовой системе грузополучатель в отношениях перевозки груза выступает третьим лицом на стороне грузоотправителя, так как у грузоотправителя и грузополучателя существует обязательственная связь из иного договора между ними, где отправитель обязуется предоставить получателю определенные вещи посредством использования транспортных услуг перевозчика. Такая обязательственная связь не обязательно должна быть возмездной. Грузополучатель - это лицо, в пользу которого заключается и исполняется договор перевозки груза между отправителем и перевозчиком.

\section{ЛИТЕРАТУРА}

1. Гражданский кодекс Российской Федерации (часть первая) от 30.11.1994 N 51-Ф3 (ред. от 31.07.2020) // СЗ РФ. 1994. N 32. Ст. 3301.

2. Гражданский кодекс Российской Федерации (часть вторая) от 26.01.1996 N 14-Ф3 (ред. от 27.12.2019, с изМ. от 28.04.2020) // С РФ. 1996. N 5. Ст. 410.

3. Воздушный кодекс Российской Федерации от 19.03.1997 N 60-Ф3 (ред. от 08.06.2020) // СЗ РФ. 1997. N 12. Ст. 1383.

4. Кодекс торгового мореплавания Российской Федерации от 30.04.1999 N 81-Ф3 (ред. от 13.07.2020) // СЗ РФ. 1999. N 18. С. 2207.

5. Александров-Дольник М.К. Содержание договора грузовой перевозки // Советское государство и право. 1954. N 4. С. 107.

6. Брагинский М.И., Витрянский В.В. Договорное право. Кн. 4: Договоры о перевозке, буксировке, транспортной экспедиции и иных услугах в сфере транспорта. М., 2003. С. 293 - 297.

7. Зарапина Л.В. 0 статусе грузополучателя в договоре перевозки грузов // Вестник Московского финансово-юридического университета. 2016. N 4.

8. Шайдуллина В.К. Договор перевозки грузов: дис. ... канд. юрид. наук. М., 2016. С. 22.

(с) Спектор Асия Ахметовна (spektor_roat_dot@bk.ru ). 